\title{
Review
}

\section{Lowering the milk lactose content in vivo: potential interests, strategies and physiological consequences}

\author{
Jean-Luc VILOTTE*
}

Laboratoire de Génétique Biochimique et de Cytogénétique, Département de Génétique Animale, Institut National de la Recherche Agronomique, 78352 Jouy-en-Josas Cedex, France

\begin{abstract}
Lactose is the major sugar present in milk and an important osmotic regulator of lactation. It is digested by intestinal lactase, an enzyme expressed in new-borns. Its activity declines following weaning. As a result, adult mammals are normally lactose-intolerant and more than $75 \%$ of the human adult population suffers from lactase deficiency. A reduction in milk lactose content could be beneficial for nutritional but also agricultural and industrial purposes (less volume to transport, better milk coagulation, less effluent production). Several attempts to create transgenic mice producing milk with modified carbohydrate compositions have recently been described. Depending on whether these modifications resulted from an alteration of lactose synthesis or from lactose hydrolysis, striking physiological differences are observed.
\end{abstract}

lactose / osmolarity / milk / transgenic / mice

Résumé - Diminution in vivo de la teneur du lait en lactose : intérêt, stratégies et conséquences physiologiques. Le lactose est le principal sucre du lait et un important régulateur osmotique de la lactation. Il est digéré par la lactase intestinale, enzyme exprimée chez les nouveau-nés dont l'activité décroît après le sevrage. De fait, les mammifères adultes sont normalement intolérants au lactose et plus de $75 \%$ de la population adulte mondiale souffre d'hypolactasia. Une diminution de la teneur en lactose du lait serait bénéfique d'un point de vue nutritionnel mais également pour l'agriculture et l'industrie (moins de volume à transporter, meilleure coagulation et moins de rejets). Plusieurs approches ont permis d'obtenir des souris transgéniques produisant un lait dont la composition en carbohydrates était modifiée. Selon que la cible de ces modifications était la synthèse du lactose ou ce sucre lui-même, les conséquences physiologiques étaient fort différentes.

lactose / osmolarité / lait / transgénèse / souris

\footnotetext{
* Correspondence and reprints

E-mail: vilotte@jouy.inra.fr
} 


\section{INTRODUCTION}

$\alpha$-lactalbumin ( $\alpha$ lac), one of the major milk protein present in almost all mammalian milks that has structural and sequence similarity to the C-type lysozyme, has been proposed to be at the origin of lactation because of its biological activity [8]. By interacting with the $\beta 1->4$ UDP-galactosyltransferase (EC 2.4.1.38), $\alpha$-lactalbumin modifies substrate specificity of this enzyme virtually creating a unique binding site for glucose [4]. It leads to the synthesis of lactose, a predominant sugar in milk and a key osmotic regulator of lactation.

Lactose is hydrolysed by intestinal lactase, lactase-phlorizin hydrolase (EC 3.2.1.62-108). This enzyme is expressed in young mammals, but its activity declines following weaning. Thus adult mammals are normally unable to digest lactose leading to potential intestinal disorders following milk ingestion. More than $75 \%$ of the human adult population 'suffers' from hypolactasia $[21,27]$. Lactose maldigestion could also result from intestinal pathologies or congenital alactasia [22, 30]. A low lactose milk can therefore be seen as a nutraceutical, as already suggested back in 1986 [15]. If associated with a reduction in milk volume, a low lactose milk could also have interesting agricultural and industrial properties such as the possibility to reduce the volumes that have to be transported, better milk coagulation and the rejection of less effluent.

In wild populations, natural synthesis of low lactose is observed. Sea mammals, such as the northern fur seal [2] and the California sea lion [19], produce highly concentrated milks with no detectable lactose. This absence of lactose is related to the lack of detectable $\alpha$ lac [17]. In late lactation, the Macropus eugenii Tammar wallaby and the Monodelphis domestica didelphid marsupial produce a milk devoid of lactose despite high concentrations of $\alpha$ lac. This probably results from the increase at the physiological stage in enzymatic activities degrading either UDP-galactose or lactose in the mammary gland and/or milk $[6,16]$.

\section{ALTERING LACTOSE SYNTHESIS}

\subsection{Targeting $\alpha$ lac expression}

Since $\alpha$ lac is known to alter the enzymatic specificity of UDP-galactosyltransferase promoting lactose synthesis, one could speculate that the absence or a significant diminution of $\alpha$ lac synthesis in the mammary epithelial cell would result in a concomitant lack or decrease of lactose synthesis. However, $\alpha$ lac has other attributed functions such as that of a releasing factor for lysozomal enzymes [11, 12], a growth inhibitory action on epithelial cells [29] and an inducer of apoptosis [7, 28]. Furthermore, it was not known before the experiments described below were undertaken whether or not $\alpha$ lac is the only protein susceptible to induce lactose synthesis in vivo.

Two alac-null alleles were created using homologous recombination in ES cells [24, 26]. Transgenic mice bearing these alleles at a homozygous stage were derived [25, 26]. The observed Mendelian rate of transmission of either of the two null alleles suggests that $\alpha$ lac is not required for normal development. Homozygous transgenic females produce a highly viscous milk, rich in fat and proteins, devoid of detectable lactose, that pups are unable to suckle, demonstrating that alac is needed to induce lactose synthesis. Heterozygous transgenic females synthesises a similar milk, besides a $50 \%$ lower $\alpha$ lac content, to that of their non-transgenic littermates suggesting that $\alpha$ lac is in excess with regards to its biological function. Thus decreasing the milk lactose content through a reduction in the level of the alac gene expression will require diminishing it by more than $50 \%$.

An attempt to do so using additive transgenesis, which so far remains the mostly used strategy in farm animals, probably 
failed because this gene is highly expressed in the mammary gland. The strategy used was based on the targeting of a ribozyme [13]. Although highly specific, this approach allows only a $50 \%$ decrease of alac in the best line, which is an insufficient reduction to affect the milk lactose content. However, alternative strategies do exist such as the attachment of a constitutive transport element to the ribozyme to increase its efficiency [31] or the use of the promising but yet unfully validated for such purposes RNA interference ([3,14] for reviews).

Until better knowledge of the structurefunction relationship of $\alpha$ lac is gained, expression of a dominant negative protein, which would bind to the UDP-galactosyltransferase with at least the same affinity as $\alpha$ lac but without promoting lactose synthesis, appears to be a very difficult goal to reach. However this would avoid decreasing the alac milk content which could have a negative nutritional impact since this protein is an important supply of essential amino acids [9].

\subsection{Targeting UDP-galactosyltrans- ferase expression}

UDP-galactosyltransferase is a ubiquitously expressed gene [20]. Beside a housekeeping promoter, expression of this gene is driven by a mammary gland specific promoter which allows a 10 -fold increase in the level of this protein in the lactating mammary gland compared to other somatic tissues [20].

A $\beta 1$-> 4 UDP-galactosyltransferasenull allele was obtained by homologous recombination in ES cells [1]. Mice homozygous for this allele suffer from various disorders such as growth retardation, skin and small intestine epithelial cell proliferation, abnormal differentiation in intestinal villi and semi-lethality. Females are fertile and can give birth. The milk produced lacks lactose and as observed for $\alpha$ lac-deficient mice, it is too viscous for pups to suckle it.
Although no other analysis was performed on this milk, it strongly suggests that the absence of either of the two components of the lactose-synthetase resulted in a very similar phenotype in terms of milk production.

Interestingly, mice heterozygous for the $\beta 1->4$ UDP-galactosyltransferase-null allele could rear their offspring despite producing milk with about half as much lactose as in non-transgenic littermates. This suggests that $\beta 1->4$ UDP-galactosyltransferase is a limiting factor for lactose synthesis in vivo. Affecting its mammary expression level would thus be much more efficient in decreasing lactose synthesis than affecting the alac gene expression. Restricting this process to the mammary tissue should also avoid the various disorders observed when gene expression is ubiquitously affected. To achieve this, two strategies could be used: (i) in the mammary cells, targeting the expression of RNA that will interfere with that of this gene, such as antisens, ribozymes or maybe double-stranded RNA, or (ii) specifically altering the transcriptional activity of the mammary-specific promoter. This latter option, which will need the use of homologous recombination, is somehow complicated because the tissue-specific promoter is located 3' of the housekeeping one, within the first exon of the ubiquitously used transcription unit [20]. Drastic alteration of its sequence might also disturb the gene expression in other tissues. However, specific transcription factor-binding sites have been associated with the mammary-gland specific promoter activity [20]. Specific mutation of these sites might only affect the expression of the $\beta 1$-> 4 UDP-galactosyltransferase gene in the lactating epithelial cells, a hypothesis yet to be tested.

\subsection{Other potential targets?}

As already mentioned, in late lactation of the Macropus eugenii Tammar wallaby and of the Monodelphis domestica didelphid marsupial, it has been suggested that an 
increase in enzymatic activities degrading UDP-galactose could explain the lack of lactose despite the presence of alac [6, 16]. $\alpha$-galactosidase and/or nucleotide pyrophosphatase are potential enzymes that could degrade UDP-galactose. The occurrence of the latter in the bovine milk fat globule membrane has been reported [18]. However, the implication of either of these two enzymes appears unlikely because of the phenotype observed. Indeed, one would expect that a decrease in the availability of UDP-galactosyltransferase will concomitantly induce an increase in milk osmolarity, as observed with the two above-mentioned knock-out experiments.

Nevertheless, targeting expression of either or both enzymes in the lactating mammary gland using classical additive transgenesis may be an interesting approach which is yet to be tested.

\section{DEGRADING LACTOSE IN SITU}

Secretion of active $\beta$-galactosidase into milk to hydrolyse lactose in situ was suggested back in 1986 [15]. Its successful realisation in transgenic mice was only recently published [10]. To do this, targeting expression in the mammary gland of the rat intestinal lactase-phlorizin hydrolase is performed. Although only the precursor but not the mature protein is produced in the mammary gland, this protein is active. Located at the apical side of the epithelial cells as well as in the membrane of the internal secretary vesicles and of the fat globules, its activity resulted in a 50 to $85 \%$ reduction in milk lactose content.

The decrease in lactose content is not associated with an increase in milk osmolarity, as observed in the knockout experiments. Milk nutritional value, solids, protein, fat, sodium and potassium concentrations were unaffected whereas glucose and galactose contents increased although not proportionally. This approach is thus adapted to producing a milk suitable for people suffering from hypolactasia. It remains to be demonstrated whether the physiological consequences of lactase expression will be the same in ruminants.

Experiments designed to analyse milk properties in transgenic mice expressing lactase revealed that lactose hydrolysis occurs within the epithelial cells [10]. Despite a $50 \%$ decrease in lactose content, milk osmolarity is not affected suggesting that there is not a linear relationship between lactose and the secretory vesicle water content. It was also observed that milk storage in the mammary gland results in a further decrease in lactose content but similar levels of glucose and galactose, again with no increase in milk osmolarity. This observation strongly suggests that either a very low amount of lactose is needed or, more likely, that the polarity of the epithelial cells is such that no water flow from the secretory vesicles and alveoli towards the cells is possible. Glucose is known to be transported across the plasma and Golgi membranes of the mammary epithelial cells by specific transporters, such as Glut 1 [5, 23, 32, 33]. However, most of these experiments suggested that these transporters are not located at the apical membrane. The observed results in the lactase-transgenic mice suggest that monosaccharides present in milk can be reabsorbed, at least partially, by the alveolar cells. Whether this is a passive phenomenon or whether it implies the occurrence of transporters within the apical membrane remains to be determined.

\section{CONCLUSION}

In vivo production of a low lactose milk has been achieved in transgenic mice using various strategies. Depending on the molecule that was targeted in this metabolic pathway, striking different physiological consequences were observed. Expression of lactase is probably an attractive approach to produce a milk adapted to people 
suffering from hypolactasia and one could expect that transgenic ruminants will soon be obtained to this aim. The concomitant reduction in the milk volume, which could be of interest for agricultural and industrial purposes, is feasible but the current applied technologies need further improvements before they may be transposed to large animals.

\section{REFERENCES}

[1] Asano M., Furukawa K., Kido M., Matsumoto S., Umesaki Y., Kochibe N., Iwakura Y., Growth retardation and early death of $\beta 1,4$-galactosyltransferase knockout mice with augmented proliferation and abnormal differentiation of epithelial cells, EMBO J. 16 (1997) 1850-1857.

[2] Ashworth U.S., Ramaiah G.D., Keyes M.C., Species difference in the composition of milk with special reference to the northern fur seal, J. Dairy Sci. 49 (1966) 1206-1211.

[3] Bosher J.M., Labouesse M., RNA interference: genetic wand and genetic watchdog, Nat. Cell Biol. 2 (2000) 31-36.

[4] Brew K., Vanaman T.C., Hill R.L., The role of $\alpha$-lactalbumin and the A protein in lactose synthetase: a unique mechanism for the control of a biological reaction, Proc. Natl. Acad. Sci. USA 59 (1968) 491-497.

[5] Burnol A.F., Leturque A., Loizeau M., Postic C., Girard J., Glucose transporter expression in rat mammary gland, Biochem. J. 270 (1990) 277-279.

[6] Crisp E.A., Messer M., VandeBerg J.L., Changes in milk carbohydrates during lactation in a didelphid marsupial, Monodelphis domestica, Physiol. Zool. 62 (1989) 1117-1125.

[7] Hakansson A., Zhivotovsky B., Orrenius S., Sarbharwal H., Svanborg C., Apoptosis induced by a human milk protein, Proc. Natl. Acad. Sci. USA 92 (1995) 8064-8068.

[8] Hayssen V., Blackburn D.G., Alpha-lactalbumin and the origins of lactation, Evolution 39 (1985) 1147-1149.

[9] Heine W., Radke M., Wutzke K.D., Peters E., Kundt G., $\beta$-lactalbumin-enriched low protein infant formulas: a comparison to breast milk feeding, Acta Paediatr. 85 (1996) 1024-1028.

[10] Jost B., Vilotte J.L., Duluc I., Rodeau J.L., Freund J.N., Production of low-lactose milk by ectopic expression of intestinal lactase in the mouse mammary gland, Nat. Biotechnol. 17 (1999) 160-164.

[11] Komine S., Nakanishi K., Anzai T., Yoshimoto A., $\alpha$-lactalbumin as a lysosomal enzyme-releasing factor, Cell Biochem. Funct. 3 (1985) 33-39.
[12] Komine S., Nakanishi K., Anzai T., Yoshimoto A., Process of the combination of $\alpha$-lactalbumin with lysosomes in mammary epithelial cells, Cell Biochem. Funct. 3 (1985) 41-44.

[13] L'Huillier P.J., Soulier S., Stinnakre M.G., Lepourry L., Davis S.R., Mercier J.C., Vilotte J.L., Efficient and specific ribozyme-mediated reduction of bovine $\alpha$-lactalbumin expression in double transgenic mice, Proc. Natl. Acad. Sci. USA 93 (1996) 6698-6703.

[14] Marx J., Interfering with gene expression, Science 288 (2000) 1370-1372.

[15] Mercier J.C., Genetic engineering applied to milk producing animals: some expectations, in: Smith C., King J.W.B., McKays J.C. (Eds.), Exploiting technologies in animal breedinggenetic development, Oxford University Press, Oxford, 1986, pp. 122-131.

[16] Messer M., Elliott C., Changes in $\alpha$-lactalbumin, total lactose, UDP-galactose hydrolase and other factors in Tammar Wallaby (Macropus eugenii) milk during lactation, Aust. J. Biol. Sci. 40 (1987) 37-46.

[17] Nicholas K., Whitley J., Cane K., Wells M., Digby M., Trott J., Simpson K., Molecular mechanisms regulating lactation in marsupials and pinnipeds, opportunities for the dairy industry, Second International Workshop on Mammary Gland Biotechnology, COST B20, Budapest, 2001, pp. 26-27.

[18] Patton S., Trams E.G., The presence of plasma membrane enzymes on the surface of bovine milk fat globules, FEBS Lett. 14 (1971) 230-232.

[19] Pilson M.E.Q., Kelly A.L., Composition of the milk from Zalophus californianus, the california sea lion, Science 135 (1962) 104-105.

[20] Rajput B., Shaper N.L., Shaper J.H., Transcriptional regulation of murine $\beta 1,4$-galactosyltransferase in somatic cells, J. Biol. Chem. 271 (1996) 5131-5142.

[21] Sahi T., Genetics and epidemiology of adult type hypolactasia, Scand. J. Gastroenterol. 29 (1994) 7-20.

[22] Savilahti E., Launiala K., Kuitunen P., Congenital lactase deficiency, Arch. Dis. Child. 58 (1983) 246-252.

[23] Shennan D.B., Beechey R.B., Mechanisms involved in the uptake of D-glucose into the milk producing cells of rat mammary tissue, Biochem. Biophys. Res. Comm. 211 (1995) 986-990.

[24] Stacey A., Schnieke A., McWhir J., Cooper J., Colman A., Melton D.W., Use of doublereplacement gene targeting to replace murine $\alpha$-lactalbumin gene with its human counterpart in embryonic stem cells and mice, Mol. Cell. Biol. 14 (1994) 1009-1016. 
[25] Stacey A., Schnieke A., Kerr M., Scott A., McKee C., Cottingham I., Binas B., Wilde C., Colman A., Lactation is disrupted by $\alpha$-lactalbumin deficiency and can be restored by human $\alpha$-lactalbumin gene replacement in mice, Proc. Natl. Acad. Sci. USA 92 (1995) 2835-2839.

[26] Stinnakre M.G., Vilotte J.L., Soulier S., Mercier J.C., Creation and phenotypic analysis of $\alpha$-lactalbumin-deficient mice, Proc. Natl. Acad. Sci. USA 91 (1994) 6544-6548.

[27] Suarez F.L., Savaiano D.A., Levitt M.D., The treatment of lactose intolerance, Aliment. Pharmacol. Ther. 9 (1995) 589-597.

[28] Svensson M., Hakansson A., Mossberg A.K., Linse S., Svanborg C., Conversion of $\alpha$-lactalbumin to a protein inducing apoptosis, Proc. Natl. Acad. Sci. USA 97 (2000) 4221-4226.

[29] Thompson M.P., Farrell H.M., Mohanam S., Liu S., Kidwell W.R., Bansal M.P., Cook R.G.,
Medina D., Kotts C.E., Bano M., Identification of human milk $\alpha$-lactalbumin as a cell growth inhibitor, Protoplasma 167 (1992) 134-144.

[30] Villako K., Maaroos H., Clinical picture of hypolactasia and lactose intolerance, Scand. J. Gastroenterol. 29 (1994) 36-54.

[31] Warashima M., Kuwabara T., Kato Y., Sano M., Taira K., RNA-protein hybrid ribozymes that efficiently cleave any mRNA independently of the structure of the target RNA, Proc. Natl. Acad. Sci. USA 98 (2001) 5572-5577.

[32] Zhao F.Q., Dixon W.T., Kennelly J.J., Localization and gene expression of glucose transporters in bovine mammary gland, Comp. Biochem. Physiol. B Biochem. Mol. Biol. 115 (1996) 127-134.

[33] Zhao F.Q., Okine E.K., Kennelly J.J., Glucose transporter gene expression in bovine mammary gland, J. Anim. Sci. 77 (1999) 2517-2522.

To access this journal online: www.edpsciences.org 